\title{
Den psykologiske betydning af Irans atomprogram
}

\section{Sadegh Zibakalam}

\section{Otte års krig mod Irak lærte iranerne, at i denne verden er de overladt til sig selv. Så det var ingen tilfældighed, at den iranske ledelses topprioritet efter krigen var at gøre Iran til en atommagt}

Lige siden det iranske atomprogram blev afsløret i 2003, har utallige artikler, rapporter og analyser undersøgt forskellige aspekter heraf. Der er dog ét vigtigt aspekt, som ikke er blevet forstået fuldt ud. Det drejer sig om atomprogrammets psykologiske betydning for mange iranere, herunder en stor del af landets lederskab.

Atomprogrammet har givet mange iranere en følelse af tryghed, en forsikring mod at blive angrebet af det islamiske styres magtfulde fjender. Nogle analytikere afviser måske denne vurdering og giver det islamiske styres egen opførsel skylden for at skabe reelle eller indbildte fjender.

Men selv om det er sandt, at Irans opførsel internationalt ikke lader det tilbage med mange venner, især ikke under den nuværende hardliner præsident, så er mange iraneres trusselsopfattelse langt mere kompliceret end præsident Mahmoud Ahmadinejads opførsel lader formode, og den stikker langt dybere end de sidste fire år, hvor Ahmadinejad har været ved magten. Det omstændighed, at atomprogrammet blev påbegyndt i slutningen af 1980'erne og begyndelsen af 1990'erne, viser at de dybereliggende årsager hertil blev grundlagt i 1980'erne

\section{Ingen frygt for verden udenfor}

Under kampen mod den afdøde shah af Iran i 1978 og 1979 følte de islamiske ledere, inklusive nu afdøde imam Ruhollah Khomeini, at den omliggende verden, herunder vestmagterne, ikke var imod dem. Der herskede en følelse af selvretfærdighed og selvtillid, som blev 
styrket efter revolutionen. De internationale medier behandlede de iranske ledere som helte, der havde omstyrtet en skånselsløs og despotisk hersker. Det islamiske styre blev budt velkomment af de store verdensmagter, der straks anerkendte det. Carter-administrationen tøvede naturligvis noget med at oprette fulde diplomatiske forbindelser med det nye islamiske styre, men resten af verden var klar til at knytte bånd med Teheran.

Kort fortalt havde de islamiske ledere ikke grund til at frygte verden udenfor. De gik så vidt som til at afbestille nogle af de avancerede våbensystemer, som shahen havde bestilt i USA. Listen omfattede langtrækkende missiler, avancerede kampfly, antiluft missiler, undervandsbåde, krigsskibe og andet militært isenkram.

Med rette eller urette følte den første generation af islamiske ledere, at Iran ikke havde nogen fjender, ikke havde noget udestående med dets naboer og ikke påtænkte at bekæmpe andre stater. Det behøvede derfor ikke de enorme lagre af våben, som shahen havde samlet, og som han fortsatte med at modtage fra USA indtil sit fald. I virkeligheden havde shahens modstandere, inklusive de islamister, som nu havde magten, altid kritiseret shahens politik med at spille rollen som 'Den Persiske Golfs politibetjent'.

At udskifte landets tanks med traktorer var ironisk nok et slogan, som ayatollah Khomeini mange år tidligere havde brugt i et af sine angreb på shahen.

\section{Bitre lektier}

Men krigen mod Irak ændrede i høj grad denne indledende eufori. Til at begynde med havde iranerne aldrig forestillet sig, at irakerne ville invadere deres territorium. Som et retfærdigt, populært, revolutionært og islamisk styre, støttet af 98,5 pct. af befolkningen, var det utænkeligt for de iranske ledere og den iranske offentlighed i almindelighed at forestille sig, at et andet land ville angribe dem.

Endnu mere uforståeligt var det, at verden bare ville forholde sig passivt og ikke engang fordømme Saddams invasion af deres land. Til iranernes forbløffelse og skræk var hverken Vest eller Øst, hverken de islamiske stater eller den arabiske verden, faktisk ingen overhovedet, rede til at fordømme Saddams invasion af Iran for slet ikke at tale om at hjælpe Iran med at forsvare sig mod den mægtige irakiske hær. Tværtimod opfordrede alle - EF, FN's Sikkerhedsråd, Irans arabiske naboer og muslimske ledere - gentagne gange Iran til at beherske sig og 'prøve at finde en fredelige løsning på konflikten'.

De nye iranske ledere lærte deres første bitre diplomatiske lektie: Hvis du vil være uafhængig af både Vest og Øst (et af den islamiske revolutions vigtigste slogans), så vil ingen af 
dem hjælpe dig, selv om du er offer for de groveste krænkelser af internationale regler og normer. Iranerne lærte at frem for at vente på, at det internationale samfund skulle træde i aktion for at tvinge irakerne til at forlade deres land, måtte de stole på sig selv.

Men iranerne måtte lære flere bitre lektier. Efter at de med enorme tab havde tvunget irakerne tilbage og vundet verdens beundring, blev iranerne endnu engang rådet til at acceptere våbenstilstand $o g$ forhandle med det irakiske styre. Selv modstandere af styret svarede verden: "Hvad med retfærdighed, skal dem, der invaderer andre lande, gå ustraffet?"

Verdens reaktion var den samme, da irakerne krænkede internationale konventioner og brugte kemiske våben. Til iranernes skræk vendte verden endnu engang det blinde øje til Saddams grusomheder, da tusindvis af iranere blev dræbt af disse våben.

\section{Atom-kreditkortet}

Otte års krig mod Irak lærte iranerne, at de i denne verden er overladt til sig selv. Ironisk nok oplevede mange iranere under krigen den samme følelse af at være ensom og forladt af verden udenfor, som mange jøder må have følt i koncentrationslejrene under Holocaust. Så det var ikke en tilfældighed, at det umiddelbart efter krigen blev en topprioritet for den iranske ledelse at gøre Iran til en atommagt.

Det er yderligere ironisk, at Vestens reaktion på Irans atomprogram har bevist over for iranerne, at de så sandelig er slået ind på rette kurs. Irans atomprogram er det eneste område, hvor Vesten har taget iranerne alvorligt i de seneste tre årtier. Vesten har således utilsigtet lært de iranske ledere, at man kun bliver taget alvorligt, når man stikker verden sit 'atom-kreditkort'.

Sadegh Zibakalam er professor i Iranske Studier ved Teheran Universitet.

Artiklen er offentliggjort $i$ bitterlemonsinternational.org, edition 10 volume 7 , den 28. maj.

(c) bitterlemons-international.org.

Oversat fra engelsk af Brita $V$. Andersen. 